ISSN 0258-7122

Bangladesh J. Agril. Res. 36(1) : 87-95, March 2011

\title{
COMPARATIVE ADVANTAGE OF VEGETABLES PRODUCTION IN BANGLADESH
}

\author{
M. R. KARIM ${ }^{1}$, S. HOSSAIN ${ }^{2}$, M. A. RASHID ${ }^{3}$ \\ M. A.K. AZAD ${ }^{4}$ AND M.A.H.S. JAHAN ${ }^{5}$
}

\begin{abstract}
The study was undertaken to assess the comparative advantage of production and export of vegetables from Bangladesh. Fifty four kinds of different vegetables were exported from Bangladesh. The importing countries were mostly in the Middle East. The demand for summer vegetables was found higher than those of winter vegetables. Total export quantity was found 6046 metric tons of vegetables and earned foreign exchange of Tk. 1120 million, which was only 1.18 percent of total value of vegetable production in Bangladesh. Among the export marketing cost items, air freights charges was found highest. For all the vegetables, DRCs were observed to be less than unity implying that Bangladesh had comparative advantage in vegetable production.
\end{abstract}

Keywords: Export potential, vegetables, foreign exchange earnings.

\section{Introduction}

As many as 54 different kinds of vegetables were exported from Bangladesh (UNCTAD, 2008). It is an important sector in the total agricultural exports of Bangladesh (Karim, 2008). After independence, vegetables were started to export in a very limited scale. Vegetables and fruits are being exported from Bangladesh since 1980s. Bangladesh has achieved a remarkable progress in export of agricultural products. Export earning from agricultural products have increased 12.9 \% during 2003-04 in comparison with previous year (Quasem, 2003). The vegetable sector, occupying a more or less significant position in our export sector, helps meet our need of foreign currency as well as ensure our economic development. Bangladesh earns Tk. 1456.33 million (US\$ 24.70 million) in the year 2003-04 by exporting vegetables, which constitutes 60.08 percent of the earnings from agricultural products (Karim et al., 2005).

The quantity of export is not big, but sizeable enough to create market for the large ethnic population of the South Asian sub-continent residing in the UK and Gulf region. They have proved to be the largest consumer of Bangladeshi vegetables. But, they demanded more summer vegetables than those of winter vegetables. A large portion of all vegetables were exported, especially to the South

\footnotetext{
${ }^{1 \& 2}$ Senior Scientific Officer, Chief Scientific Officer and Head, respectively, Agril. Econ. Divin., ${ }^{3}$ Senior Scientific Officer, T \& C Wing, Bangladesh Agricultural Research Institute (BARI), Gazipur 1701, ${ }^{4}$ Senior Asstt. Secretary, Ministry of Planning, Sher-eBangla Nager, Dhaka-1207 and ${ }^{5}$ Senior Scientific Officer, WRC, BARI, Gazipur 1701, Bangladesh.
} 
Asian sub-continent and Gulf region. The demand for Bangladeshi vegetables is increasing in the South Asian sub-continent and Gulf region day by day. It is important to mention here that relatively low marketing cost was incurred for exporting vegetables in the Middle East. So the exporters could be able to earn more foreign exchange by exporting vegetables. In order to formulate an appropriate policy for exporting vegetables, it is needed to estimate the efficiency of production in relation to comparative advantage of vegetables. So, the present study has been undertaken to highlight the economic performance of vegetables.

\section{Methodology}

In order to evaluate the efficiency of production in relation to comparative advantage, cost of both domestic resource and non-traded inputs and traded inputs for production of vegetables are needed. Domestic resource and nontraded inputs include human labour, animal labour, seed, manure, irrigation, land rent, interest on operating capital, etc. while traded inputs include Urea, TSP, MP, and Gypsum. Using the above information, domestic resource cost (DRC) was estimated for different vegetables. The domestic resource cost (DRC) provides a measure of efficiency with implications for the level of incentives offered to producers. Whether the vegetable growers are efficient to produce a commodity as opposed to importing it, depends on the opportunity cost of domestic production relative to the value added. The DRC is the ratio of cost of domestic resources and non-traded inputs (valued at their shadow prices) of producing the commodity to the net foreign exchange earned or saved by producing the good domestically. Formally DRC is defined as:

Cost of domestic resource and non - traded inputs for producing

$$
\mathrm{DRC}=
$$
vegetable/metric ton

Mathematically

$\mathrm{DRC}=\frac{\Sigma \mathrm{D}_{i j} \mathrm{~V}_{i}}{B_{i}-\Sigma \mathrm{T}_{i k} \mathrm{~V}_{k}}(\mathrm{j}=1$----------------m, $\mathrm{k}=1$---------------n)

Where,

$\mathrm{D}_{\mathrm{ij}}=$ domestic resource and non-traded inputs $\mathrm{j}$ used for producing vegetable $\mathrm{i} /$ metric ton,

$\mathrm{V}_{\mathrm{i}}=$ Price of domestic resource and non-traded inputs $\mathrm{j}$,

$\mathrm{B}_{\mathrm{i}}=$ Border price of vegetable $\mathrm{i} /$ metric ton,

$\mathrm{T}_{\mathrm{ik}}=$ Quantity of tradable inputs $\mathrm{k}$ for producing vegetable $\mathrm{i} /$ metric ton and

$\mathrm{V}_{\mathrm{k}}=$ Border price of tradable inputs $\mathrm{k} /$ metric ton.

If $\mathrm{DRC}<1$, the economy saves foreign exchange by producing the vegetables domestically either for export or import substitution. This is because 
the opportunity cost of domestic resources and non-traded inputs used in producing the vegetable is less than the foreign exchange earned or saved. In contrast, if DRC > I, domestic costs are in excess of foreign costs or savings indicating that the vegetable should not be produced domestically and should be imported instead.

\section{Results and Discussion}

\section{Exportable vegetables from Bangladesh}

Appendix 1 shows the number of vegetables exported from Bangladesh to abroad. Vegetables were exported to those countries where Bangladeshis and other ethnic Asians live. Export of vegetables are confined mostly in those countries where Bangladeshis are also living. Though the number of exported items is large, the quantities are small. Position of Bangladesh as an exporter of vegetables is almost unsatisfactory to the world export particularly if compared with our neighboring country India. Bangladesh vegetables being exported to about 25 countries including KSA, UAE, Qatar, Oman, etc. and United Kingdom.

\section{Annual trend of export of vegetables}

Table 1 shows the annual quantity of vegetables export from Bangladesh during the period 1992-93 to 2006-07 (BBS 2005, Krishi Diary 2008) with their average prices shown in Table 3. The table exhibits the present status of vegetables export. It was observed that the vegetables export from Bangladesh is declining since 2001. In 1997-98, annual vegetable export was 23,597 tons but in 2006-07, it was only 4361 tons. This situation caused by many of reasons, such as reduced outflow of migrant workers, higher air freight charge and quality deterioration of vegetables.

Table 1. Total export quantity (MT) of vegetables.

\begin{tabular}{cc}
\hline Year & Quantity (MT) \\
\hline $1992-93$ & 8042.00 \\
$1993-94$ & 7415.00 \\
$1994-95$ & 8270.00 \\
$1995-96$ & 12932.00 \\
$1996-97$ & 20449.00 \\
$1997-98$ & 23597.00 \\
$1998-99$ & 13106.00 \\
$1999-00$ & 10270.00 \\
$2000-01$ & 9509.00 \\
$2001-02$ & 12799.00 \\
$2002-03$ & 7007.00 \\
$2003-04$ & 7777.00 \\
$2004-05$ & 12302.00 \\
$2005-06$ & 6046.00 \\
$2006-07$ & 4361.00 \\
\hline
\end{tabular}

Source: BBS 2005. Krishi Diary 2008, DD (Plant protection Wing), Quarantine Office, DAE. Khamarbari, Dhaka. 


\section{Export earning from vegetables in 2005-06}

Table 2 represents the foreign exchange earnings from export of vegetables. Highest export earning was found by exporting potato followed by brinjal, pointed gourd, latiraj, etc. In the year 2005-06, the total export earning from vegetables was estimated to be Tk. 1120 million (Table 2). Total export earning from vegetables was found to be 1.18 percent of the value of total vegetables production.

Table 2. Foreign exchange earnings from exporting (Million Tk.) vegetable in 2005-06.

\begin{tabular}{|c|c|c|c|c|}
\hline Name of vegetables & $\begin{array}{l}\text { Total export } \\
\text { (Million Tk.) }\end{array}$ & $\begin{array}{c}\text { Total } \\
\text { consumption } \\
\text { at home } \\
\text { (Million Tk.) }\end{array}$ & $\begin{array}{l}\text { Total } \\
\text { production } \\
\text { (Million } \\
\text { Tk.) }\end{array}$ & $\begin{array}{c}\text { Export earning as } \\
\% \text { of total value of } \\
\text { vegetable production }\end{array}$ \\
\hline Pumpkin & 11 & 1227 & 1238 & 0.9 \\
\hline Brinjal & 101 & 11262 & 11362 & 0.9 \\
\hline Pointed gourd & 78 & 1378 & 1457 & 5.4 \\
\hline Okra & 67 & 434 & 501 & 13.4 \\
\hline Ridge gourd & 11 & 422 & 433 & 2.6 \\
\hline Bitter gourd & 45 & 1261 & 1306 & 0.4 \\
\hline Eddoe & 56 & 2359 & 2415 & 0.3 \\
\hline White gourd & 34 & 587 & 620 & 5.4 \\
\hline Cucumber & 22 & 3594 & 3616 & 0.6 \\
\hline Yardlong bean & 45 & 404 & 449 & 10.0 \\
\hline 1.spinach & 11 & 849 & 860 & 1.3 \\
\hline Snake gourd & 22 & 451 & 474 & 4.7 \\
\hline Stem Amaran. & 56 & 592 & 648 & 8.6 \\
\hline Teasle gourd & 45 & 1165 & 1210 & 3.7 \\
\hline Sponge gourd & 22 & 663 & 686 & 3.3 \\
\hline Latiraj & 78 & 1585 & 1664 & 4.7 \\
\hline C.flower & - & 2640 & 2640 & - \\
\hline Cabbage & 11 & 5023 & 5034 & 0.2 \\
\hline Bottle gourd & 22 & 1100 & 1122 & 2.0 \\
\hline Tomato & - & 11542 & 11542 & - \\
\hline Radish & - & 6837 & 6837 & - \\
\hline C. bean & 22 & 556 & 578 & 3.9 \\
\hline Red Amarnth & 22 & 650 & 672 & 3.3 \\
\hline Potato & 123 & 36584 & 36708 & 0.3 \\
\hline Sub-total & 907 & 93164 & 94071 & 1.0 \\
\hline Export other veg. & 213 & - & - & - \\
\hline Total export & 1120 & - & - & - \\
\hline Grand total & - & - & 95191 & - \\
\hline \multicolumn{4}{|c|}{ Total export earning (\%) from total vegetable production } & 1.18 \\
\hline
\end{tabular}

Source: Own Estimation. 
Table 3. Average selling price (TkIMT) of vegetables in abroad in 2005-06.

\begin{tabular}{cc}
\hline Name of country & Tk./MT \\
\hline Middle East & $1,85,247.00$ \\
UK & $2,25,135.00$ \\
\hline
\end{tabular}

Source: Different Exporters of Sham Bazar, Dhaka.

\section{Export cost of vegetables in 2005-06}

As many as 23 items of costs were involved in case of vegetables export. Of these, air freights charges was found to be Tk. 111250/MT for Middle East countries, while it was Tk. 160000/MT for UK. Among the cost items, air freights charges were found highest. In spite of the highest air freights charges, the exporters earned profit Tk. 31983/MT and it was found to be Tk. 32/kg (Table 4) in the Middle East countries. The lion share of vegetables was exported to the Middle East countries.

Table 4. Export cost of vegetables in 2005-06.

\begin{tabular}{|c|c|c|}
\hline Cost items & Middle East & UK \\
\hline Packaging & 3020.00 & 3184.00 \\
\hline Packaging materials & 3488.00 & 3730.00 \\
\hline Grading \& loading & 960.00 & 1064.00 \\
\hline Transport cost (Go-down to airport & 1700.00 & 1870.00 \\
\hline Unloading & 176.00 & 186.00 \\
\hline Air freights charges & 111250.00 & 160000.00 \\
\hline Airway bill charges (documentation) & 216.00 & 238.00 \\
\hline Terminal \& Handling & 2440.00 & 2440.00 \\
\hline Export performa (EXP) charges & 500.00 & 500.00 \\
\hline GSP certificate charges & 0.00 & 300.00 \\
\hline Phyto-sanitary certificate & 0.00 & 200.00 \\
\hline Bank services & 50.00 & 50.00 \\
\hline Quarantine & 100.00 & 100.00 \\
\hline Metropolitan chamber offices charges & 500.00 & 500.00 \\
\hline Dhaka Chamber of Commerce Office Charges & 1500.00 & 1500.00 \\
\hline Clearing \& forwarding charges & 1000.00 & 1000.00 \\
\hline Miscellaneous & 150.00 & 150.00 \\
\hline Exporters’ office expenses & 2200.00 & 2272.00 \\
\hline Salary \& Wages & 920.00 & 1020.00 \\
\hline Office \& go-down rent & 910.00 & 1020.00 \\
\hline Tele. fax, Email, Photocopy etc. & 252.00 & 276.00 \\
\hline Entertainment & 334.00 & 368.00 \\
\hline Commission Agent & 500.00 & 500.00 \\
\hline Total Cost & 132166.00 & 182468.00 \\
\hline Total Cost except air Fare & 20916.00 & 22468.00 \\
\hline Price in abroad & 153082.00 & 204936.00 \\
\hline Selling price in abroad & 185247.00 & 225135.00 \\
\hline Profit (Tk./MT) & 32165.00 & 20199.00 \\
\hline Profit (Tk./kg) & 32.17 & 20.20 \\
\hline
\end{tabular}

Source: Different Exporters of Sham Bazar, Dhaka 


\section{Comparative advantages of vegetables}

As mentioned earlier, DRC indicates whether the domestic economy has a comparative advantage in vegetables crops relative to other countries. If the DRC is greater than one, it implies that the economy loses foreign exchange through domestic production of the vegetables (in the sense that it uses more domestic resources than it generates net value added to tradable goods and services), while DRC is less than one implies that the production is efficient and make positive contribution to domestic value addition. The estimates of DRCs for different vegetables for the year 2005-06 are presented in Table 5. Among vegetables, the lowest DRC was found in snake gourd, while it was found highest in bitter gourd. Besides, the DRCs were found far below the one. The DRCs for all the vegetables were observed to be less than unity implying that Bangladesh had comparative advantage in vegetables production. On an average, DRC was found far below i.e. 0.35 (Table 5). It is, therefore, concluded here that exporting vegetables to Middle East countries has the higher comparative advantage in vegetables production to a greater extent.

Table 5. Domestic resource cost (DRC) of different vegetables in the year 2005-06.

\begin{tabular}{l|cc|c|c}
\hline \multirow{2}{*}{$\begin{array}{c}\text { Name of } \\
\text { vegetables }\end{array}$} & $\begin{array}{c}\text { Non-traded input } \\
\text { cost }\end{array}$ & $\begin{array}{c}\text { Traded input } \\
\text { cost }\end{array}$ & $\begin{array}{c}\text { f.o.b. price at } \\
\text { airport }\end{array}$ & \multirow{2}{*}{ DRC ratio } \\
\cline { 2 - 4 } Snake gourd & Tk./MT & Tk./MT & Tk./MT & \\
Brinjal & 2379.00 & 293.00 & 15600.00 & 0.16 \\
Yardlong bean & 4177.00 & 1045.00 & 25250.00 & 0.17 \\
Okra & 3359.00 & 1233.00 & 20500.00 & 0.17 \\
Potato & 4085.00 & 1661.00 & 17950.00 & 0.25 \\
Red amaranth & 4692.00 & 913.00 & 18000.00 & 0.27 \\
Cucumber & 4808.00 & 922.00 & 17500.00 & 0.29 \\
Eddoe & 5502.00 & 329.00 & 17900.00 & 0.31 \\
Country bean & 5797.00 & 760.00 & 18800.00 & 0.32 \\
Teasle gourd & 16460.00 & 1422.00 & 35400.00 & 0.00 \\
White gourd & 9524.00 & 455.00 & 17640.00 & 0.48 \\
Pointed gourd & 11292.00 & 2039.00 & 20850.00 & 0.55 \\
Bitter gourd & 14695.00 & 1451.00 & 24780.00 & 0.60 \\
Average & 7339.08 & 998.31 & 21097.69 & 0.35 \\
\hline
\end{tabular}

Source: Authors’ own estimation. 


\section{Conclusion}

The exporters will be able to earn a sizeable amount of foreign exchange through exporting vegetable, especially in the Middle East countries if the bottlenecks to the export can be minimized through different government actions. So the Government should liberalize our vegetables exporting policy by any means. In order to do so, it may be concluded here that the downward trend of vegetable export is to be changed to upward trend of vegetable export.

\section{References}

Agricultural Information Service (AIS). 2008. Krishi Diary. Ministry of Agriculture. Government of the People's Republic of Bangladesh

Bangladesh Bureau of Statistics (BBS). 2005. Ministry of Planning, Government of the People's Republic of Bangladesh

Karim, Z. 2008. Current farm level fertilizer situation and agricultural productivity in Bangladesh. A report submitted to the country office of FAO in Bangladesh.

Karim, M. R., M.A. Matin, Tanvir M.B. Hossain and M.I. Hossain. 2005 Vegetable marketing and Its export potentials in Bangladesh. Annual Research Report of Agricultural Economics Division, BARI, Joydebpur, Gazipur-1701.

Quasem, M.A.2003. Export of fresh horticultural crops from Bangladesh: Problems and prospects. A first draft report presented at BARC, on 21 August.

UNCTAD. 2008. Sub-regional workshop environmental Requirements, Market access/entry and export competitiveness in the horticultural Sector, Bangkok, Thailand.

Appendix 1. List of exportable vegetables from Bangladesh.

\begin{tabular}{c|l|l}
\hline SI. No. & English name of vegetables & Local name of vegetables \\
\hline 1 & Bitter gourd & Karala \\
2 & Yard long bean & Barbati \\
3 & Okra & Dherosh \\
4 & Bottle gourd/Dudhi & Bottle gourd \\
5 & Ash/wax gourd & Jali Kumra \\
6 & Snake gourd & Chickingal Kohi \\
7 & Sponge gourd & Dundul \\
8 & Green chilli & Kacha Marich \\
9 & Ridge gourd & Jhinga/Tury \\
10 & Pumpkin//Sweet gourd & Misti Kumra \\
11 & Pointed gourd & Patal/PaIwal \\
12 & Teasle gourd & Kakrol/Kantola \\
13 & Cucumber & Shasa \\
14 & Broccoli & Sabuj Phulkopi \\
15 & Hyacinth bean/Lablab bean & Deshi seem \\
16 & French bean & French bean \\
\hline
\end{tabular}


Appendix 1. Cont'd

\begin{tabular}{|c|c|c|}
\hline SI. No. & English name of vegetables & Local name of vegetables \\
\hline 17 & Small cucumber & Khira \\
\hline 18 & Potato & GoolAlu \\
\hline 19 & Egg plant/brinjal & Kalo Begun \\
\hline 20 & Taro & Pani Kachu \\
\hline 21 & Eddoe & Mukhi Kachu \\
\hline 22 & Coco Yam & Dood Kachu \\
\hline 23 & Yautia & Moulavi Kachu \\
\hline 24 & Giant Taro & Mankachu \\
\hline 25 & Aroid & Kachu \\
\hline 26 & Stolon of Taro & Kachur Lati \\
\hline 27 & White Yam & Mattay Alu \\
\hline 28 & Air potato & PestaAlu \\
\hline 29 & Elephant foot yam & Olkachu \\
\hline 30 & Green Papaya & Kacha Papay \\
\hline 31 & Drumstick & Shajna \\
\hline 32 & Plantain & Kacha Kola \\
\hline 33 & Banaba Flower & Kolar Thor/Mocha \\
\hline 34 & Water Lity & Shapla \\
\hline 35 & Pea seed & Motor Shuti \\
\hline 36 & Stem Amaranth & Danta \\
\hline 37 & Red amaranth & Lalshk \\
\hline 38 & Indian Spinach & Puishak \\
\hline 39 & Spinach & Palong Shak \\
\hline 40 & Kangkong & Gimakalmi Shak \\
\hline 41 & Sweet potato & Misti alu \\
\hline 42 & Jute leaf & Patshak \\
\hline 43 & Rajatpata & Rajatpata \\
\hline 44 & Belet leaf & Pan \\
\hline 45 & Stem Amaranth leaf & Danta Shak \\
\hline 46 & Leaves of Aroid & Kachur pata \\
\hline 47 & Stem of Aroid & Kachur Doga \\
\hline 48 & Naga hot chilli & Naga Marich \\
\hline 49 & Onion leaf & Piaj Pata \\
\hline 50 & Matured Wax gourd & Chuna Jali Kumra \\
\hline 51 & Stem of Banana & Kolar Anaj \\
\hline 52 & Hyacinth bean seed & Seemer Bichi \\
\hline 53 & Bottle gourd leaf & Lau Shak \\
\hline 54 & Cabbage & BadhaKopi \\
\hline 55 & Coriander leaf & Dhaney Pata \\
\hline
\end{tabular}

Source: Different Exporters of Sham bazar, Dhaka. 
Appendix 2. Farm-gate prices of different vegetables (TkIMT) in 2005-06.

\begin{tabular}{l|l}
\hline Name of vegetables & Tk./MT \\
\hline Pumpkin & 5529 \\
Brinjal & 6079 \\
Pointed gourd & 7650 \\
Okra & 6059 \\
Ridge gourd & 7568 \\
Bitter gourd & 8925 \\
Eddoe & 5661 \\
White gourd & 4865 \\
Cucumber & 5110 \\
Yardlong bean & 9000 \\
l.spinach & 3590 \\
Snake gourd & 6630 \\
Stem Amaran. & 8500 \\
Teasle gourd & 17500 \\
Sponge gourd & 6550 \\
Latiraj & 15040 \\
C.flower & 7568 \\
Cabbage & 5488 \\
Bottle gourd & 4702 \\
Tomato & 9160 \\
Radish & 3825 \\
C. bean & 6946 \\
Red Amarn. & 8500 \\
Potato & 8045 \\
& \\
\hline &
\end{tabular}

Source: Sonali Bank, Foreign Exchange Branch, Dhaka.

Appendix 3. Conversion rate of foreign currency in 2005-06.

\begin{tabular}{cccc}
\hline Foreign currency & In-terms of Tk. & In-terms of US dollar \\
\hline US dollar & 67.07 & 1.00 \\
Uro & 81.40 & 1.21 \\
Pound & 118.78 & 1.77 \\
Average & 89.08 & 1.33 \\
\hline
\end{tabular}

Source: DAM and BBS. 